\title{
Faktor-Faktor yang Memengaruhi Kepatuhan Wajib Pajak dalam Membayar Pajak Kendaraan Bermotor di Kota Denpasar
}

\author{
Anak Agung Ngurah Krisnadeva ${ }^{1}$ \\ Fakultas Ekonomi dan Bisnis \\ Universitas Udayana, Indonesia \\ Email: krisnadeva45@gmail.com
}

\author{
Ni Ketut Lely Aryani Merkusiwati² \\ Fakultas Ekonomi dan Bisnis \\ Universitas Udayana, Indonesia
}

\begin{abstract}
ABSTRAK
Penelitian ini bertujuan untuk memperoleh bukti empiris mengenai pengaruh tingkat pendapatan wajib pajak kesadaran wajib pajak, kualitas pelayanan, dan sanksi perpajakan pada kepatuhan wajib pajak dalam membayar pajak kendaraan bermotor di Kota Denpasar. Teori yang digunakan yaitu teori akuntansi keperilakuan sebagai grand theory dan teori atribusi sebagai teori pendukung. Populasi yaitu seluruh wajib pajak PKB aktif yang terdaftar di Kantor Bersama SAMSAT Kota Denpasar sejumlah 713.601. Sampel penelitian sebanyak 100 responden dihitung berdasarkan rumus Slovin dengan metode accidental sampling. Pengumpulan data dengan metode kuesioner dan teknik dokumentasi. Teknik analisis data yaitu analisis regresi linier berganda. Hasil penelitian menunjukkan tingkat pendapatan wajib pajak, kesadaran wajib pajak, kualitas pelayanan dan sanksi perpajakan berpengaruh positif pada kepatuhan wajib pajak dalam membayar pajak kendaraan bermotor di Kota Denpasar
\end{abstract}

Kata Kunci: Tingkat Pendapatan; Kesadaran; Kualitas Pelayanan; Sanksi Perpajakan; Kepatuhan Wajib Pajak Kendaraan Bermotor.

\section{Factors That Affect Taxpayer Compliance in Paying Motor Vehicle Tax in Denpasar City}

\section{ABSTRACT}

This study aims to obtain empirical evidence about the influence of taxpayer income levels, taxpayer awareness, service quality, and tax penalties on tax compliance in paying motor vehicle tax in Denpasar. The theory used is behavioral accounting theory as grand theory and attribution theory as supporting theory. The population is all active PKB taxpayers registered at the Joint Office of SAMSAT Denpasar City totaling 713,601. The research sample of 100 respondents was calculated based on the Slovin formula with the accidental sampling method. Data collection by questionnaire method and documentation technique. The data analysis technique is multiple linear regression analysis. The results showed the level of taxpayer income, taxpayer awareness, service quality and tax penalties had a positive effect on taxpayer compliance in paying motor vehicle tax in Denpasar.

Keywords: Income Levels; Awareness; Service Quality; Tax Penalties; Motor Vehicle Taxpayer Compliance.

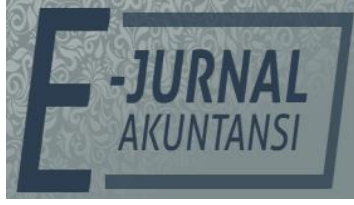

E-JA

e-Jurnal Akuntansi e-ISSN 2302-8556

Vol. 30 No. 6 Denpasar, Juni 2020

Hal.1425-1440

Artikel Masuk: 28 Januari 2020

Tanggal Diterima: 17 Maret 2020

This Article is Avalilable in: https://ojs.unud.ac.id/index.php/Akuntansi/index 


\section{PENDAHULUAN}

Hampir seluruh daerah di Indonesia menggali potensi pendapatannya melalui pajak daerah, maka pemerintah daerah harus mampu meningkatkan sumber potensi pendapatan daerah melalui pajak daerah agar pembangunan dan roda pemerintahan berjalan sebagaimana mestinya. Undang-Undang No. 28 Tahun 2009 Tentang Pajak Daerah dan Retribusi Daerah, menyatakan bahwa pajak daerah digunakan untuk keperluan daerah, selanjutnya disebut pajak, adalah kontribusi wajib kepada daerah yang terutang oleh orang pribadi atau badan yang bersifat memaksa berdasarkan undang-undang, dengan tidak mendapatkan imbalan secara langsung. Pajak daerah menurut Mardiasmo (2018:14) adalah iuran wajib yang dilakukan oleh orang pribadi atau badan kepada daerah tanpa imbalan langsung yang seimbang, yang dapat dipaksakan berdasarkan peraturan perundang-undangan yang berlaku, yang digunakan untuk membiayai penyelenggaraan pemerintah daerah dan pembangunan daerah. Nurmianti (2014) menyatakan bahwa pembangunan nasional adalah pembangunan yang berlangsung secara terus menerus dan berkesinambungan serta merata di seluruh tanah air yang bertujuan untuk mencerdaskan kehidupan bangsa dan untuk mensejahterakan rakyat Indonesia secara adil dan merata. Pembangunan nasional secara merata (seluruh daerah) memerlukan peran pemerintah yang handal. Pemerintah daerah dalam hal ini harus cermat memanfaatkan dana yang tersedia untuk pembangunan daerahnya masingmasing, karena pembangunan daerah memerlukan dana yang tidak sedikit.

Undang-Undang No. 28 Tahun 2009 Tentang Pajak Daerah dan Retribusi Daerah meneyebutkan bahwa jenis pajak daerah khususnya pajak provinsi terdiri dari lima jenis pajak, antara lain: Pajak Kendaraan Bermotor (PKB), Bea Balik Nama Kendaraan Bermotor (BBNKB), Pajak Bahan Bakar Kendaraan Bermotor, Pajak Air Permukaan dan Pajak Rokok. Peraturan Daerah Provinsi Bali No.1 Tahun 2011 Tentang Pajak Daerah, pajak kendaraan bermotor adalah pajak atas kepemilikan ataupun penguasaan kendaraan bermotor. Wajib pajak kendaraan bermotor yaitu orang pribadi, bad an ataupun instansi pemerintahan yang mempunyai kendaraan bermotor. Pemungutan pajak kendaraan bermotor dapat dihitung dengan mempertimbangkan dua unsur pokok yaitu nilai jual kendaraan bermotor dan bobot yang menjelaskan secara relatif kadar kerusakan jalan ataupun pencemaran lingkungan yang diakibatkan oleh penggunaan kendaraan bermotor. Peraturan Daerah Provinsi Bali No.1 Tahun 2011 pasal 9 ayat 1 menyatakan pajak kendaraan bermotor yang terutang dipungut pada wilayah daerah tempat kendaraan bermotor tersebut terdaftar. Wajib pajak kendaraan bermotor yaitu orang pribadi, badan ataupun instansi pemerintahan yang mempunyai kendaraan bermotor.

lnstansi yang menangani pembayaran pajak kendaraan bermotor adalah Badan Pendapatan Daerah (Bapenda) melalui Kantor Bersama Sistem Administrasi Manunggal Satu Atap (SAMSAT) yang merupakan kerja sama tiga instansi terkait, yaitu Bapenda, Kepolisian Republik Indonesia dan Asuransi Jasa Raharja.

Selama 5 Tahun terakhir yaitu Tahun 2014-2018 Kota Denpasar memiliki peningkatan jumlah kendaraan bermotor yang cukup signifikan dibandingkan dengan peningkatan jumlah kendaraan bermotor Kabupaten lain selama Tahun 2014-2018 di Provinsi Bali yang dapat dilihat pada Tabel 1. sebagai berikut. 
Tabel 1. Jumlah Kendaraan Bermotor pada Masing-masing Kabupaten atau Kota di Provinsi Bali Tahun 2014-2018

\begin{tabular}{llllll}
\hline Kabupaten / Kota & 2014 & 2015 & 2016 & 2017 & 2018 \\
\hline Kab. Jembrana & 162.061 & 173.678 & 183.416 & 191.778 & 200.932 \\
Kab. Tabanan & 329.266 & 351.829 & 370.487 & 386.821 & 404.804 \\
Kab. Badung & 663.708 & 713.479 & 755.706 & 796.567 & 844.680 \\
Kab. Gianyar & 341.530 & 367.057 & 388.365 & 408.582 & 432.012 \\
Kab. Klungkung & 96.956 & 105.569 & 113.242 & 120.692 & 128.680 \\
Kab. Bangli & 86.866 & 94.412 & 101.056 & 107.472 & 114.413 \\
Kab. Karangasem & 139.127 & 152.677 & 164.724 & 176.829 & 190.108 \\
Kab. Buleleng & 334.090 & 360.208 & 382.901 & 403.590 & 426.958 \\
Kota Denpasar & 1.114 .508 & 1.187 .075 & 1.243 .145 & 1.292 .618 & 1.353 .577 \\
Sumber: Data Penelitian, 2019 & & & &
\end{tabular}

Peningkatan jumlah kendaraan bermotor di Kota Denpasar secara terus menerus selama lima tahun terakhir yaitu Tahun 2014 sampai Tahun 2018 yang tidak diikuti dengan jumlah peningkatan realisasi penerimaan pembayaran pajak kendaraan bermotor, yang dapat dilihat pada Tabel 2. sebagai berikut.

Tabel 2. Unit yang Terealisasi dan yang Menunggak di Kantor Bersama SAMSAT Kota Denpasar Tahun 2014-2018

\begin{tabular}{llll}
\hline Tahun & $\begin{array}{l}\text { Jumlah yang } \\
\text { Terealisasi (Unit) }\end{array}$ & $\begin{array}{l}\text { Jumlah yang } \\
\text { Menunggak } \\
\text { (Unit) }\end{array}$ & $\begin{array}{l}\text { Presentase Unit yang } \\
\text { Menunggak (Persen) }\end{array}$ \\
\hline 2014 & 756.730 & 357.778 & 32,10 \\
2015 & 765.726 & 421.349 & 35,49 \\
2016 & 748.113 & 495.032 & 39,82 \\
2017 & 739.312 & 553.306 & 42,80 \\
2018 & 713.601 & 639.976 & 47,28 \\
\hline
\end{tabular}

Sumber: Data Penelitian, 2019

Peningkatan jumlah kendaraan bermotor yang signifikan setiap tahun di Kota Denpasar yang diikuti dengan peningkatan jumlah unit yang menunggak membuat penelitian dengan topik kepatuhan wajib pajak kendaraan bermotor di Kota Denpasar menarik untuk diteliti kembali.

Faktor yang memengaruhi penerimaan pajak suatu negara diantaranya adalah tingkat kepatuhan wajib pajak di negara tersebut Ariyanto, et al. (2020) Chau \& Leung, (2009). Kepatuhan wajib pajak mempunyai hubungan dengan penerimaan pajak karena apabila kepatuhan dari wajib pajak meningkat, maka secara tidak langsung juga akan memperbesar penerimaan negara dari sektor pajak (Wardani \& Rumiyatun, 2017). Gersovitz \& Hammer (2013) dan Ariyanto et al. (2020) menyatakan bahwa masalah kepatuhan wajib pajak adalah masalah yang penting di seluruh dunia, baik itu di negara maju maupun di negara berkembang, karena jika wajib pajak tidak patuh maka akan menimbulkan keinginan untuk melakukan tindakan penghindaran, pengelakan, dan pelalaian pajak. Mencapai tingkat kepatuhan saat ini merupakan isu yang menjadi perhatian para pembuat kebijakan baik di negara maju maupun negara berkembang Ariyanto et al. (2020) dan Razak \& Adafula (2013). Kepatuhan berfokus pada moral dan etika dari wajib pajak yang merupakan faktor psikologi 
yang memengaruhi wajib pajak dalam memenuhi kewajiban pajaknya (Oladipopu \& Obazee, 2016).

Resmi (2013) menyatakan bahwa, pajak sebagai suatu kewajiban menyerahkan sebagian dari kekayaan ke kas negara yang disebabkan suatu keadaan, kejadian, dan perbuatan yang memberikan kedudukan tertentu, tetapi bukan sebagai hukuman, menurut peraturan yang ditetapkan pemerintah serta dapat dipaksakan, tetapi tidak ada jasa timbal balik dari negara secara langsung untuk memelihara kesejahteraan secara umum. Pendapatan adalah sejumlah penghasilan yang diperoleh masyarakat atas prestasi kerjanya dalam periode tertentu, baik harian, mingguan, bulanan maupun tahunan (Sukirno, 2006). Penerimaan atau pendapatan yang bersumber dari ruang lingkup yang luas dikenal dengan pendapatan nasional dan daerah.

Kesadaran perpajakan adalah keadaan mengetahui atau mengerti perihal pajak tanpa adanya paksaan dari pihak lain (Wardani \& Rumiyatun, 2017). Kesadaran dan kepatuhan masyarakat akan peraturan perpajakan tentunya akan berimbas pada peningkatan penerimaan pajak negara (Marti et al., 2019). Kesadaran wajib pajak dapat dilihat dari kesungguhan dan keinginan wajib pajak untuk memenuhi kewajiban pajaknya yang ditunjukkan dalam pemahaman wajib pajak terhadap fungsi pajak dan kesungguhan wajib pajak dalam membayar dan melaporkan pajak (Suriambawa \& Setiawan, 2018).

Berdasarkan UU No. 25 Tahun 2009 Tentang Pelayanan Publik, pelayanan adalah rangkaian aktifitas dalam hal memenuhi kebutuhan pelayanan, sesuai dengan peraturan undang-undang atas barang, jasa ataupun pelayanan administrasi yang diberikan oleh pemerintah. Kualitas pelayanan dapat didefinisikan sebagai kemampuan dari suatu organisasi dalam memenuhi atau melebihi harapan pelanggan (Parasuraman et al., 1985). Kualitas pelayanan tidak hanya diangap penting oleh perusahaan komersial saja, tetapi saat ini instansi pajak juga telah merasakan pentingnya kualitas pelayanan karena instansi pajak juga memiliki pelanggan yaitu wajib pajak (Alabede et al., 2011). Rasa senang maupun puas mengenai pelayanan yang diperoleh dari pemerintah bisa memberikan motivasi dan kepatuhan untuk wajib pajak yang pada akhirnya dapat membuat penerimaan kas negara menjadi meningkat (Hanousek \& Palda, 2004). Jika persepsi wajib pajak pada kualitas pelayanan fiskus yang dipandang sangat baik, akan membuat persepsi wajib pajak terhadap pelayanan akan semakin meningkat (Murti et al, 2014).

Mencegah ketidakpatuhan serta untuk mendorong wajib pajak untuk memenuhi kewajiabm perpajakannya maka haruslah diberlakukan sanksi yang tegas dalam rangka untuk memajukan keadilan dan efektifitas perpajakan Ariyanto et al. (2020) dan Webley et al. (1991). Sanksi perpajakan merupakan sebuah jaminan bahwa ketentuan peraturan perundang-undangan perpajakan akan dipatuhi, dengan kata lain, sanksi perpajakan merupakan alat pencegah agar wajib pajak tidak melanggar norma perpajakan (Mardiasmo, 2018:62). Sanksi perpajakan memiliki peran penting guna memberikan pelajaran bagi pelanggar wajib pajak agar tidak meremehkan peraturan perpajakan. Sanksi yang diberikan bersifat memaksa semata-mata untuk memberikan efek jera agar wajib pajak tidak melanggar peraturan dan menjalankan kewajibannya sebagai wajib pajak (Adi \& Yushita, 2013). Wajib pajak yang melanggar tetapi tidak 
dikenakan sanksi perpajakan akan menyebabkan wajib pajak menganggap kewajiban perpajakannya merupakan hal yang tidak penting. Wajib pajak akan memenuhi kewajiban perpajakan bila memandang bahwa sanksi perpajakan akan lebih banyak merugikannya (Jatmiko \& Pamudji, 2016).

Berdasarkan latar belakang maka perumusan masalah penelitian ini, yaitu apakah tingkat pendapatan, kesadaran, kualitas pelayanan, dan sanksi perpajakan berpengaruh pada kepatuhan wajib pajak dalam membayar pajak kendaraan bermotor di Kota Denpasar. Tujuan penelitian untuk membuktikan secara empiris bahwa tingkat pendapatan, kesadaran, kualitas pelayanan, dan sanksi perpajakan berpengaruh pada kepatuhan wajib pajak dalam membayar pajak kendaraan bermotor di Kota Denpasar. Manfaat teoritis diharapkan dapat menambah pengetahuan, wawasan, tambahan referensi, dan acuan tentang pengaruh tingkat pendapatan wajib pajak, kesadaran wajib pajak, kualitas pelayanan, dan sanksi perpajakan pada kepatuhan wajib pajak dalam membayar pajak kendaraan bermotor di Kota Denpasar bagi mahasiswa, peneliti selanjutnya. Manfaat praktis diharapkan dapat memberikan masukan-masukan bagi Kantor Bersama SAMSAT Kota Denpasar atau pun pihak pembuat kebijakan perpajakan untuk dapat lebih memahami tentang faktor-faktor yang dapat memengaruhi kepatuhan wajib pajak dalam membayar pajak kendaraan bermotor dan dapat menjadi bahan evaluasi dimasa yang akan datang.

Akuntansi keperilakuan membahas bagaimana perilaku manusia memengaruhi informasi akuntansi dan keputusan-keputusan bisnis serta bagaimana informasi akuntansi tersebut memengaruhi perilaku manusia dan keputusan-keputusan bisnis (Supriyono, 2018). Akuntansi keperilakuan adalah suatu studi tentang perilaku akuntan atau non-akuntan yang dipengaruhi oleh fungsi-fungsi akuntansi dan pelaporan (Suartana, 2010:1). Informasi ekonomi dapat ditambah dengan tidak hanya melaporkan data-data keuangan saja, tetapi juga data-data nonkeuangan yang terkait dengan proses pengambilan keputusan (Ardiansyah, 2009). Akuntan ilmu keperilakuan memfokuskan pada hubungan antara perilaku manusia dan sistem akuntansi, mereka menyadari bahwa proses akuntansi termasuk di dalamnya meringkas sejumlah kejadian ekonomi dimana hal-hal tersebut merupakan akibat dari perilaku manusia dan bahwa pengukuran akuntansi yang mereka lakukan dapat memengaruhi perilaku, yang menentukan sukses tidaknya kejadian ekonomi (Hasnianti \& Jamaludin, 2019).

Teori atribusi mengasumsikan bahwa orang mencoba untuk menentukan mengapa orang melakukan apa yang mereka lakukan, yaitu atribusi menyebabkan perilaku (Oktaviani et al, 2017). Teori ini mengacu tentang bagaimana seseorang menjelaskan penyebab perilaku orang lain atau dirinya sendiri yang akan ditentukan apakah dari internal ataupun eksternal y ang akan memberikan pengaruh terhadap perilaku individu (Nisa \& Umar, 2019). Atribusi internal adalah kekuatan internal atau disposisi (unsur psikologis yang mendahului tingkah laku) yang merubah tingkah laku seseorang (Darwati, 2015). Atribusi internal adalah tingkah laku seseorang yang disebabkan secara internal yaitu perilaku yang disebabkan oleh kendali individu itu sendiri. Atribusi eksternal adalah kekuatan-kekuatan lingkungan yang merubah tingkah laku seseorang (Darwati, 2015). Teori atribusi dalam penelitian ini relevan untuk dijadikan teori pendukung karena teori atribusi menjelaskan tingkah laku wajib 
pajak yang disebabkan oleh atribusi internal (tingkat pendapatan masing-masing wajib pajak dan kesadaran wajib pajak) dan atribusi eksternal (kualitas pelayanan dan sanksi perpajakan) yang merubah sikap sesorang, yaitu sikap untuk membayarkan pajak kendaraan bermotornya. Kepatuhan wajib pajak adalah suatu keadaan wajib pajak dimana wajib pajak memenuhi semua hal yang menjadi kewajiban-kewajiban perpajakannya dan melaksanakan hak-hak pajak yang didapat oleh wajib pajak (Alfiansyah, 2013).

Teori akuntansi keperilakuan relevan untuk menjelaskan bahwa perilaku wajib pajak (akuntan atau non akuntan) yang dipengaruhi oleh fungsi-fungsi akuntansi dan pelaporan. Pendapatan wajib pajak yang berbeda-beda akan memengaruhi pola pikir wajib pajak dalam membayarkan pajak kendaraan bermotornya. Penelitian Mardiana et al. (2016) menyatakan bahwa pendapatan wajib pajak berpengaruh positif pada kepatuhan wajib pajak kendaraan bermotor, selaras dengan penelitian Isawati et al. (2016) \& (Farandy 2018). Semakin tinggi pendapatan wajib pajak maka semakin tinggi tingkat kepatuhan wajib pajak. Berdasarkan teori dan penelitian sebelumnya, maka dapat dirumuskan hipotesis sebagai berikut.

$\mathrm{H}_{1}$ : Tingkat pendapatan wajib pajak berpengaruh positif pada kepatuhan wajib pajak dalam membayar pajak kendaraan bermotor di Kota Denpasar.

Teori akuntansi keperilakuan menjelaskan bahwa informasi ekonomi dapat ditambah dengan tidak hanya melaporkan data-data keuangan saja, tetapi juga data-data non keuangan yang terkait dengan proses pengambilan keputusan (Ardiansyah, 2009). Kesadaran wajib pajak merupakan kondisi wajib pajak mengetahui, mematuhi, dan melaksanakan kewajiban perpajakan dengan benar dan sukarela (Megawangi \& Setiawan, 2017). Teori akuntansi keperilakuan relevan untuk menjelaskan bahwa kesadaran wajib pajak (non keuangan) yaitu keadaan dimana wajib pajak menyadari akan pentingnya pajak tanpa ada paksaan dari pihak lain yang diduga akan memengaruhi wajib pajak terkait dengan proses pengambilan keputusan untuk membayarkan kewajiban perpajakannya. Penelitian Nirajenani \& Merkusiwati (2018) menyatakan bahwa kesadaran wajib pajak berpengaruh positif pada kepatuhan wajib pajak kendaraan bermtor, selaras dengan penelitian (Wardani \& Rumiyatun 2017), dan (Febriyanti \& Setiawan 2017). Semakin tinggi kesadaran wajib pajak maka semakin tinggi tingkat kepatuhan wajib pajak. Berdasarkan teori dan penelitian sebelumnya, maka dapat dirumuskan hipotesis sebagai berikut.

$\mathrm{H}_{2}$ : Kesadaran wajib pajak berpengaruh positif pada kepatuhan wajib pajak dalam membayar pajak kendaraan bermotor di Kota Denpasar.

Teori akuntansi keperilakuan menjelaskan bahwa informasi ekonomi dapat ditambah dengan tidak hanya melaporkan data-data keuangan saja, tetapi juga data-data non keuangan yang terkait dengan proses pengambilan keputusan (Ardiansyah, 2009). Kualitas pelayanan adalah tingkat keunggulan yang diharapkan dan pengendalian atas tingkat keunggulan tersebut untuk memenuhi keinginan pelanggan. Meningkatkan kepatuhan wajib pajak dapat dilakukan melalui peningkatan kualitas pelayanan, pelayanan yang berkualitas merupakan pelayanan yang memberikan kepuasan kepada pelanggan. Harapan dari kualitas pelayanan yang baik adalah wajib pajak dapat memperoleh kemudahan dalam menyelesaikan kewajiban pajaknya. Pelayanan adalah model 
yang menggambarkan kondisi pelanggan dalam membentuk harapan akan layanan dari pengalaman masa lalu, promosi dari mulut ke mulut dan iklan dengan membandingkan pelayanan yang mereka harapkan dengan apa yang mereka rasakan (Kotler \& Keller, 2009). Teori akuntansi keperilakuan relevan untuk menjelaskan bahwa kualitas pelayanan (non keuangan), yaitu persepsi wajib pajak terhadap kualitas pelayanan yang diberikan oleh SAMSAT Kota Denpasar yang diduga akan memengaruhi wajib pajak terkait dengan proses pengambilan keputusan untuk membayarkan kewajiban perpajakannya. Penelitian Nirajenani \& Merkusiwati (2018) menyatakan bahwa kualitas pelayanan berpengaruh positif pada kepatuhan wajib pajak kendaraan bermotor, selaras dengan penelitian Dewi \& Jati (2018), dan Febriyanti \& Setiawan (2017). Semakin tinggi kualitas pelayanan yang diberikan maka semakin tinggi tingkat kepatuhan wajib pajak. Berdasarkan teori dan penelitian sebelumnya, maka dapat dirumuskan hipotesis sebagai berikut.

$\mathrm{H}_{3}$ : Kualitas pelayanan berpengaruh positif pada kepatuhan wajib pajak dalam membayar pajak kendaraan bermotor di Kota Denpasar.

Akuntansi keperilakuan adalah suatu studi tentang perilaku akuntan atau non-akuntan yang dipengaruhi oleh fungsi-fungsi akuntansi dan pelaporan (Suartana, 2010:1). Sanksi perpajakan merupakan peraturan undang-undangan perpajakan yang dibuat agar wajib pajak dapat menuruti, mematuhi, dan menaati peraturan tersebut. Wajib pajak dapat lebih patuh dan tepat waktu dalam membayarkan pajak kendaraan bermotornya karena adanya peraturan pemberian sanksi administrasi berupa kenaikan dan denda bunga yang dapat membuat wajib pajak memandang sanksi perpajakan akan lebih memberatkannya. Pelayanan adalah suatu proses bantuan kepada orang lain dengan cara-cara tertentu yang memerlukan kepekaan dan hubungan interpersonal agar tercipta kepuasan dan keberhasilan (Boediono et al., 2003). Teori akuntansi keperilakuan relevan untuk menjelaskan bahwa perilaku wajib pajak (akuntan atau non akuntan) yang dipengaruhi oleh fungsi-fungsi akuntansi dan pelaporan, fungsi-fungsi akuntansi tersebut adalah informasi tentang jumlah sanksi bunga dan administrasi yang akan diterima oleh wajib pajak jika tidak atau telat membayarkan kewajiban perpajakannya yang diduga akan memengaruhi perilaku wajib pajak dalam membayarkan pajak kendaraan bermotornya. Hasil penelitian Rusmayani \& Supadmi, (2018), Dewi \& Jati (2018), dan Nirajenani \& Merkusiwati (2018) menyebutkan bahwa sanksi perpajakan berpengaruh positif pada kepatuhan wajib pajak dalam memenuhi kewajiban perpajakannya. Semakin tinggi persepsi wajib pajak terhadap sanksi perpajakan yang akan lebih memberatkannya, maka semakin tinggi tingkat kepatuhan wajib pajak. Berdasarkan teori dan penelitian sebelumnya, maka dapat dirumuskan hipotesis sebagai berikut.

$\mathrm{H}_{4}$ : Sanksi perpajakan berpengaruh positif pada kepatuhan wajib pajak dalam membayar pajak kendaraan bermotor di Kota Denpasar.

\section{METODE PENELITIAN}

Data yang digunakan dalam penelitian yaitu data kualitatif, yaitu data angkaangka atau data kualitatif yang diangkakan (Sugiyono, 2018:9) berupa realisasi penerimaan dan tunggakan di Kantor Bersama SAMSAT Kota Denpasar serta 
hasil jawaban responden dari pernyataandan data kuantitatif. Data kualitatif adalah data yang berbentuk kata, kalimat, skema, dan gambar (Sugiyono, 2018:9). Data kualitatif yang digunakan dalam penelitian ini adalah sejarah berdirinya Kantor Bersama SAMSAT Kota Denpasar, struktur organisasi dan uraian tugas masing-masing bagian. Sumber data primer yaitu hasil jawabanjawaban atas pernyataan-pernyataan dalam pengisian kuesioner oleh responden dan data sekunder yaitu jumlah realisasi penerimaan dan tunggakan pajak kendaraan bermotor di Kantor Bersama SAMSAT Kota Denpasar. Penelitian ini dilakukan di Kantor Bersama SAMSAT Kota Denpasar yang beralamat di Jalan Cok Agung Tresna No.1 Renon Kota Denpasar. Alasan memilih Kantor Bersama SAMSAT Kota Denpasar.

Tingkat Pendapatan Wajib Pajak $\left(X_{1}\right)$ diartikan sebagai penghasilan yang timbul atau dihasilkan oleh wajib pajak dari aktivitasnya yaitu dari pekerjaanya dalam periode tertentu (Ronia, 2011). Indikator yang digunakan untuk mengukur pendapatan wajib pajak yaitu: (1) Taat membayar pajak meskipun pendapatan rendah; (2) Besar kecilnya pajak tidak menghalangi dalam membayar pajak; (3) Sanggup membayar besarnya pajak yang dikenakan; dan (4) Pendapatan yang diperoleh dapat memenuhi kebutuhan utama dan memenuhi kewajiban. Pengukuruan variabel tingkat pendapatan wajib pajak yang dikembangkan oleh Farandy (2018) diukur dengan 4 indikator yang terdiri dari 4 pernyataan yang dinilai menggunakan skala likert dengan nilai skor 1-5.

Kesadaran Wajib Pajak $\left(\mathrm{X}_{2}\right)$ dilihat dari kesungguhan dan keinginan wajib pajak untuk memenuhi kewajiban pajaknya sebagai kontribusi terhadap Pendapatan Asli Daerah (PAD) untuk meningkatkan pembangunan daerah guna mensejahterakan rakyat (Dharma, 2014). Indikator yang digunakan untuk mengukur kesadaran wajib pajak yaitu: (1) Pajak merupakan partisipasi dalam menunjang pembangunan daerah; (2) Penundaan pembayaran pajak dan pengurangan beban pajak sangat merugikan daerah; dan (3)Pajak kendaraan bermotor ditetapkan dengan undang-undang dan dapat dipaksakan. Pengukuruan variabel kesadaran wajib pajak yang dikembangkan oleh Susilawati (2013) diukur dengan 3 indikator yang terdiri dari 3 pernyataan yang dinilai menggunakan skala likert dengan nilai skor 1-5.

Kualitas Pelayanan $\left(\mathrm{X}_{3}\right)$ dinilai sebagai perbandingan antara harapan yang diinginkan oleh pelanggan dengan penilaian mereka terhadap kinerja aktual dari suatu penyediaan layanan (Cronin \& Taylor, 1992). Pelayanan dapat dikatan berkualitas apabila terwujudnya kepuasaan pelanggan dan adanya sikap profesionalisme fiskus dalam memberikan pelayanan (Dewi \& Jati, 2018). Indikator yang dapat digunakan untuk mengukur kualitas pelayanan yaitu: (1) Bukti langsung, yaitu meliputi fasilitas fisik, pegawai, perlengkapan, dan komunikasi; (2) Keadaan (reliability) yaitu kemampuan karyawan Kantor Besama SAMSAT Kota Denpasar dalam memberikan pelayanan yang menjanjikan dengan segera dan memuaskan; (3) Daya tanggap (responsiveness) merupakan karakteristik kecocokan dalam pelayanan manusia yaitu keinginan para petugas pajak untuk membantu wajib pajak dan memberikan pelayanan dengan tanggap; (4) Jaminan (assurance) yaitu mencakup kemampuan, kesopanan, dan sifat dapat dipercaya yang dimiliki oleh petugas pajak bebas dari resiko, bahaya atau keragu-raguan; dan (5) Empati (empathy) adalah kondisi mental yang membuat 
seseorang merasa dirinya sama dengan perasaan orang lain yang mencakup kemudahan dalam melakukan hubungan komunikasi yang baik, perhatian pribadi wajib pajak, dan memahami kebutuhan wajib pajak. Pengukuruan variabel kualitas pelayanan yang dikembangkan oleh Febriyanti \& Setiawan (2017) dan diukur dengan 5 indikator yang terdiri dari 19 item pernyataan yang dinilai menggunakan skala likert dengan nilai skor 1-5.

Sanksi Perpajakan $\left(\mathrm{X}_{4}\right)$ yaitu jaminan bahwa ketentuan peraturan perundang-undangan perpajakan (norma perpajakan) akan dituruti, ditaati atau dipatuhi, dengan maksud sanksi perpajakan merupakan alat pencegah agar wajib pajak tidak melanggar norma per pajakan (Dewi \& Jati 2018). Wajib pajak dapat dikatakan patuh ketika wajib pajak tersebut taat dan tidak terlambat dalam membayarkan pajaknya (James \& Alley, 2009). Sanksi perpajakan dalam penelitian ini diukur dengan indikator yaitu: (1) Wajib pajak mengetahui adanya sanksi perpajakan (sanksi administrasi dan sanksi pidana); (2) Sanski pajak harus dikenakan kepada pelanggar tanpa toleransi; (3) Wajib pajak membayar Pajak kendaraan bermotor tepat waktu agar terhindar dari sanksi perpajakan. Pengukuruan variabel sanksi perpajakan yang dikembangkan oleh Febriyanti (2017) diukur dengan 3 indikator yang terdiri dari 3 item pernyataan yang dinilai menggunakan skala likert dengan nilai skor 1-5.

Kepatuhan Wajib Pajak (Y) yaitu ketaatan, tunduk, dan patuh serta melaksanakan ketentuan perpajakan daerah. Kepatuhan wajib pajak kendaraan bermotor dalam membayar pajak kendaraan bermotor dapat diukur dengan indikator yaitu: (1) Peraturan pajak kendaraan bermotor harus ditaati oleh seluruh wajib pajak; (2) Mengisi formulir pajak dengan lengkap dan jelas; (3) Wajib pajak membayar pajak kendaraan bermotor dalam jumlah yang sesuai dengan yang terdapat pada STNK (Surat Tanda Nomor Kendaraan); dan (4) Membayar pajak yang terutang tepat pada waktunya. Pengukuruan variabel kepatuhan wajib pajak yang dikembangkan oleh Susilawati (2013) diukur dengan 4 indikator yang terdiri dari 4 item pernyataan yang dinilai menggunakan skala likert dengan nilai skor 1-5.

Populasi dalam penelitian ini adalah seluruh wajib pajak kendaraan bermotor yang membayarkan pajak kendaraan bermotornya di Kantor Bersama SAMSAT Kota Denpasar yang berjumlah 713.601 wajib pajak. Pengambilan sampel dengan metode accidental sampling. Jumlah sampel yang digunakan dalam penelitian ini adalah sebanyak 99,99 atau dibulatkan menjadi 100 wajib pajak kendaraan bermotor milik pribadi di Kantor Bersama SAMSAT Kota Denpasar. Metode pengumpulan data yang digunakan adalah metode survei dengan menggunakan teknik kuesioner dan teknik dokumentasi.

Data penelitian diolah dengan regresi linier berganda. Sebelum dilakukan pengujian dengan regresi linier beganda maka harus lolos uji asumsi klasik. Adapun rumus regresi linier berganda dalam penelitian ini adalah:

$$
Y=\alpha+\beta_{1} X_{1}+\beta_{2} X_{2}+\beta_{3} X_{3}+\beta_{4} X_{4}+\varepsilon
$$

Tingkat signifikansi yang digunakan dalam penelitian ini adalah $5 \%$

\section{HASIL DAN PEMBAHASAN}

Pemerintah Provinsi Daerah Tingkat I Bali mengeluarkan surat keputusan Gubernur kepada Kepala Daerah Tingkat II Bali tanggal 2 April 1977 
Nomor.2/skep/44/Pd-1/17/1977 Tentang Pembentukan Tim Bersama antara Pemerintah Daerah Tingkat I Bali, Komando Kepolisian XV Nusra, dan Badan Asuransi Jasa Raharja Daerah Bali. Tanggal 14 November 1978 dikeluarkan Surat Keputusan Gubernur Daerah Tingkat I No. Hot/III.d22/1978 Tentang Pembentukan Unit Pelaksana Pelayanan Teknis Pemungutan Pajak Kendaraan Bermotor pada Kantor Bersama SAMSAT, UPT. Dinas Pendapatan Provinsi Bali di Kota Denpasar. Setelah melalui langkah-langkah persiapan, maka di Provinsi Daerah Tingkat I Bali SAMSAT mulai dilaksanakan pada tanggal 2 Januari 1976 yang di pusatkan pada Kantor Bersama SAMSAT Kota Denpasar di Jalan Seruni Denpasar yang mewilayahi dan melayani masyarakat di seluruh Kabupaten Daerah Tingkat I yang ada di Bali yang selanjutnya Kantor Bersama SAMSAT Kota Denpasar dipindahkan di Jalan Kapten Tantular No.1 Renon Kota Denpasar.

Statistik deskriptif digunakan untuk memberikan gambaran atau deskriptif suatu data yang dilihat dari nilai rata-rata (mean), nilai minimum, nilai maksimum, dan nilai dari data penelitian. Hasil dari pengujian statistik deskriptif dari masing-masing variabel penelitian disajikan pada Tabel 3. sebagai berikut.

Tabel 3. Statistik Deskriptif

\begin{tabular}{llllll}
\hline Variabel & $\mathrm{N}$ & Minimum & Maximum & Mean & Std. Deviation \\
\hline Tingkat PendapatanWajib & 100 & 9 & 17 & 14.13 & 1.952 \\
Pajak & 100 & 11 & 20 & 14.44 & 2.253 \\
Kesadaran Wajib Pajak & 100 & 43 & 95 & 63.11 & 10.926 \\
Kualitas Pelayanan & 100 & 7 & 15 & 10.61 & 1.938 \\
Sanksi Perpajakan & 100 & 20 & 15.18 & 2.869 \\
Kepatuhan Wajib Pajak & 100 & 9 & & &
\end{tabular}

Sumber: Data Penelitian, 2019

Nilai rata-rata variabel tingkat pendapatan wajib pajak dalam membayar pajak kendaraan bermotor di Kota Denpasar sebesar 14,13. Nilai minimum sebesar 9 dan maksimum sebesar 17. Nilai standar deviasi sebesar 1,952, yang artinya sebaran data terkait dengan tingkat pendapatan wajib pajak sudah merata. Nilai rata-rata variabel kesadaran wajib pajak dalam membayar pajak kendaraan bermotor di Kota Denpasar sebesar 14,44. Nilai minimum sebesar 11 dan maksimum sebesar 20. Nilai standar deviasi sebesar 2,253, yang artinya sebaran data terkait dengan kesadaran wajib pajak sudah merata. Nilai rata-rata variabel kualitas pelayanan dalam membayar pajak kendaraan bermotor di Kota Denpasar sebesar 63,11. Nilai minimum sebesar 43 dan maksimum sebesar 95 . Nilai standar deviasi sebesar 10,926, yang artinya sebaran data terkait dengan kualitas pelayanan sudah merata. 
Tabel 4. Rangkuman Hasil Analisis Regresi Linear Berganda

\begin{tabular}{|c|c|c|c|c|c|}
\hline \multirow{2}{*}{ Model } & \multicolumn{2}{|c|}{$\begin{array}{l}\text { Unstandardized } \\
\text { Coefficients }\end{array}$} & \multirow{2}{*}{$\begin{array}{l}\text { Standardized } \\
\text { Coefficients } \\
\text { Beta }\end{array}$} & \multirow[t]{2}{*}{$\mathrm{t}$} & \multirow[t]{2}{*}{ Sig. } \\
\hline & B & Std. Error & & & \\
\hline (Constant) & -7.757 & 2.023 & & -3.835 & 0.000 \\
\hline $\begin{array}{l}\text { Tingkat Pendapatan } \\
\text { Wajib Pajak }\end{array}$ & 0.447 & 0.101 & 0.304 & 4.449 & 0.000 \\
\hline Kesadaran Wajib Pajak & 0.412 & 0.087 & 0.323 & 4.746 & 0.000 \\
\hline Kualitas Pelayanan & 0.103 & 0.019 & 0.394 & 5.523 & 0.000 \\
\hline Sanksi Perpajakan & 0.390 & 0.104 & 0.264 & 3.743 & 0.000 \\
\hline
\end{tabular}

Berdasarkan Tabel 4. dapat ditulis persamaan regresi linear berganda yaitu:

$$
Y=-7,757+0,447 X_{1}+0,412 X_{2}+0,103 X_{3}+0,390 X_{4}+\varepsilon
$$

Berdasarkan hasil perhitungan menggunakan uji regresi linier berganda pada Tabel 4. diketahui bahwa nilai $\beta_{1}$ adalah 0,447 dan signifikansi nilai $t$ sebesar 0,000 yang berarti angka tersebut lebih kecil dari nilai a yaitu 0,05. Hal ini mengartikan bahwa hipotesis pertama yang menyatakan bahwa tingkat pendapatan wajib pajak berpengaruh positif pada kepatuhan wajib pajak dalam membayar pajak kendaraan bermotor di Kota Denpasar diterima. . Teori akuntansi keperilakuan relevan untuk menjelaskan bahwa perilaku wajib pajak (akuntan atau non akuntan) yang dipengaruhi oleh fungsi-fungsi akuntansi dan pelaporan. Teori atribusi relevan untuk menjelaskan bahwa tingkah laku wajib pajak yang disebabkan oleh atribusi internal (tingkat pendapatan) yang merubah sikap sesorang, yaitu sikap untuk membayarkan pajak kendaraan bermotornya. Pendapatan wajib pajak yang berbeda-beda akan memengaruhi pola pikir wajib pajak dalam membayarkan pajak kendaraan bermotornya. Hasil penelitian ini didukung oleh teori akuntansi keperilakuan dan teori atribusi dalam menjelaskan pengaruh tingkat pendapatan wajib pajak pada kepatuhan wajib pajak dalam membayar pajak kendaraan bermotor di Kota Denpasar serta hasil penelitian ini selaras dengan penelitian Mardiana et al. (2016) Isawati et al. (2016) dan Farandy (2018) yang menyatakan bahwa tingkat pendapatan wajib pajak berpengaruh positif pada kepatuhan wajib pajak dalam membayar pajak kendaraan bermotor.

Berdasarkan hasil perhitungan menggunakan uji regresi linier berganda pada Tabel 4. diketahui bahwa nilai $\beta_{2}$ adalah 0,412 dan signifikansi nilai $t$ sebesar 0,000 yang berarti angka tersebut lebih kecil dari nilai a yaitu 0,05 . Hal ini mengartikan bahwa hipotesis pertama yang menyatakan bahwa kesadaran wajib pajak berpengaruh positif pada kepatuhan wajib pajak dalam membayar pajak kendaraan bermotor di Kota Denpasar diterima. Wardani (2017) menyatakan bahwa kesadaran perpajakan adalah keadaan mengetahui atau mengerti perihal pajak tanpa adanya paksaan dari pihak lain. Teori akuntansi keperilakuan relevan untuk menjelaskan bahwa kesadaran wajib pajak (non keuangan) yaitu keadaan dimana wajib pajak menyadari akan pentingnya pajak tanpa ada paksaan dari pihak lain yang diduga akan memengaruhi wajib pajak terkait dengan proses pengambilan keputusan untuk membayarkan kewajiban 
perpajakannya. Teori atribusi relevan untuk menjelaskan tingkah laku wajib pajak yang disebabkan oleh atribusi internal (kesadaran wajib pajak) yang merubah sikap sesorang, yaitu sikap untuk membayarkan pajak kendaraan bermotornya. Hasil penelitian ini didukung oleh teori akuntansi keperilakuan dan teori atribusi dalam menjelaskan pengaruh kesadaran wajib pajak pada kepatuhan wajib pajak dalam membayar pajak kendaraan bermotor di Kota Denpasar serta hasil penelitian ini selaras dengan penelitian Nirajenani \& Merkusiwati (2018), Wardani \& Rumiyatun (2017), dan Febriyanti \& Setiawan (2017) yang menyatakan bahwa kesadaran wajib pajak berpengaruh positif pada kepatuhan wajib pajak dalam membayar pajak kendaraan bermotor di Kota Denpasar.

Berdasarkan hasil perhitungan menggunakan Uji Regresi Linier Berganda pada Tabel 4. diketahui bahwa nilai $\beta_{3}$ adalah 0,103 dan signifikansi nilai $t$ sebesar 0,000 yang berarti angka tersebut lebih kecil dari nilai a yaitu 0,05. Hal ini mengartikan bahwa hipotesis pertama yang menyatakan bahwa kualitas pelayanan berpengaruh positif pada kepatuhan wajib pajak dalam membayar pajak kendaraan bermotor di Kota Denpasar diterima. Teori akuntansi keperilakuan relevan untuk menjelaskan bahwa kualitas pelayanan (non keuangan), yaitu persepsi wajib pajak terhadap kualitas pelayanan yang diberikan oleh SAMSAT Kota Denpasar yang diduga akan memengaruhi wajib pajak terkait dengan proses pengambilan keputusan untuk membayarkan kewajiban perpajakannya. Teori atribusi relevan untuk menjelaskan bahwa tingkah laku wajib pajak yang disebabkan oleh atribusi eksternal (kualitas pelayanan) yang merubah sikap sesorang, yaitu sikap untuk membayarkan pajak kendaraan bermotornya. Hasil penelitian ini didukung oleh teori akuntansi keperilakuan dan teori atribusi dalam menjelaskan pengaruh kualitas pelayanan pada kepatuhan wajib pajak dalam membayar pajak kendaraan bermotor di Kota Denpasar serta hasil penelitian ini selaras dengan penelitian Nirajenani \& Merkusiwati (2018), Dewi \& Jati (2018), dan Febriyanti \& Setiawan (2017) yang menyatakan bahwa kesadaran wajib pajak berpengaruh positif pada kepatuhan wajib pajak dalam membayar pajak kendaraan bermotor di Kota Denpasar.

Berdasarkan hasil perhitungan menggunakan Uji Regresi Linier Berganda pada Tabel 4. diketahui bahwa nilai $\beta_{4}$ adalah 0,390 dan signifikansi nilai $t$ sebesar 0,000 yang berarti angka tersebut lebih kecil dari nilai a yaitu 0,05. Hal ini mengartikan bahwa hipotesis pertama yang menyatakan bahwa sanksi perpajakan berpengaruh positif pada kepatuhan wajib pajak dalam membayar pajak kendaraan bermotor di Kota Denpasar diterima. Teori akuntansi keperilakuan relevan untuk menjelaskan bahwa perilaku wajib pajak (akuntan atau non akuntan) yang dipengaruhi oleh fungsi-fungsi akuntansi dan pelaporan, fungsi-fungsi akuntansi tersebut adalah informasi tentang jumlah sanksi bunga dan administrasi yang akan diterima oleh wajib pajak jika tidak atau telat membayarkan kewajiban perpajakannya yang diduga akan memengaruhi perilaku wajib pajak dalam membayarkan pajak kendaraan bermotornya. Teori atribusi relevan untuk menjelaskan bahwa tingkah laku wajib pajak yang disebabkan oleh atribusi eksternal (sanksi perpajakan) yang merubah sikap sesorang, yaitu sikap untuk membayarkan pajak kendaraan bermotornya. Hasil penelitian ini didukung oleh teori akuntansi keperilakuan 
dan teori atribusi dalam menjelaskan pengaruh sanksi perpajakan pada kepatuhan wajib pajak dalam membayar pajak kendaraan bermotor di Kota Denpasar serta hasil penelitian ini selaras dengan penelitian Rusmayani \& Supadmi (2018), Dewi \& Jati (2018), dan Nirajenani \& Merkusiwati (2018) yang menyatakan bahwa sanksi perpajakan berpengaruh positif pada kepatuhan wajib pajak dalam membayar pajak kendaraan bermotor di Kota Denpasar.

\section{SIMPULAN}

Berdasarkan analisis dan pembahasan dapat disimpulkan tingkat pendapatan, kesadaran wajib pajak, kualitas pelayanan, dan sanksi per pajakan berpengaruh positif pada kepatuhan wajib pajak dalam membayar pajak kendaraan bermotor di Kota Denpasar. Adapun saran dalam penelitian ini, yaitu

Kantor Bersama SAMSAT Kota Denpasar agar memberikan kualitas pelayanan yang semakin baik; pihak yang berwenang dalam membuat kebijakan perpajakan agar memberikan peningkatan pengenaan sanksi bunga dan administrasi bagi wajib pajak yang melanggar; serta wajib pajak diharapkan untuk lebih sadar akan pentingnya pajak sebagai Pendapatan Asli Daerah (PAD) dan mempertimbangkan pendapatan dengan kewajiban pajak kendaraan bermotornya.

\section{REFERENSI}

Adi, T. W., \& Yushita, A. N. (2013). Pengaruh Pengetahuan Perpajakan, Sanksi Pajak dan Kesadaran Wajib Pajak terhadap Kepatuhan Wajib Pajak Badan pada Kpp Pratama Cilacap Tahun 2018. Journal of Chemical Information and Modeling. https://doi.org/10.1017/CBO9781107415324.004

Alabede, J. O., Bt Zainol Ariffin, Z., \& Md Idris, K. (2011). Determinants of Tax Compliance Behaviour: A Proposed Model for Nigeria. International Research Journal of Finance and Economics Issue International Research Journal of Finance and Economics -Issue, 78(78).

Alfiansyah, F. (2013). Pengaruh Account Representative (Ar) Terhadap Kepatuhan Wajib Pajak Orang Pribadi (Kpp Pratama Sidoarjo Utara). Jurnal Akuntansi Unesa, 1(1).

Ardiansyah, M. (2009). Perkembangan Penelitian Akuntansi Keprilakuan, 5(3), 225-228.

Ariyanto, D., Andayani, G. W., \& Putri, I. G. A. P. (2020). Influence of Justice, Culture and Love of Money Towards Ethical Perception on Tax Evasion with Gender as Moderating Variable. Journal of Money Laundering Control, 23(1), 245-266. https://doi.org/10.1108/JMLC-06-2019-0047

Boediono, A., Suzuki, T., \& Godke, R. A. (2003). Comparison of Hybrid and Purebred in Vitro-Derived Cattle Embryos During in Vitro Culture. Animal Reproduction Science, 78(1-2), 1-11. https://doi.org/10.1016/S03784320(03)00065-4

Chau, G., \& Leung, P. (2009). A critical review of Fischer tax compliance model : A research synthesis. Journal of Accounting and Taxation, 1(2), 034-040. https://doi.org/10.5897/JAT09.021

Cronin, J. J., \& Taylor, S. (1992). Measuring Service Quality: A Reexamination and Extension. Journal of Marketing, 56(3), 55. https://doi.org/10.2307/1252296 
Darwati, Y. (2015). Keterlambatan Mahasiswa Dalam Studi Ditinjau dari Teori Atribusi dari Weiner.

Dewi, N. K. A. P., \& I Ketut Jati. (2018). Pengaruh Sosialisasi, Kualitas Pelayanan , Sanksi dan Biaya Kepatuhan Pada Tingkat Kepatuhan Wajib Pajak Kendaraan Bermotor Fakultas Ekonomi dan Bisnis Universitas Udayana ( Unud ), Bali , Indonesia email : ayupuspi. E-Jurnal Akuntansi Universitas Udayana, 25, 1-30.

Dharma, G. P. E., \& Suardana, K. A. (2014). Fakultas Ekonomi dan Bisnis Universitas Udayana ( Unud ), Bali, Indonesia negara untuk mengatasi masalah sosial, meningkatkan kesejahteraan dan. E-Jurnal Akuntansi Universitas Udayana, 1, 340-353.

Farandy, M. R., \& Sulitiyanti, U. (2018). Pengaruh Sanksi Administrasi, Kesadaran Wajib Pajak, Tingkat Pendapatan dan Modernisasi Sistem Administrasi Perpajakan Terhadap Kepatuhan Wajib Pajak Kendaraan Bermotor. Journal of Chemical Information and Modeling. https://doi.org/10.1017/CBO9781107415324.004

Febriyanti, A. A. I. I., \& Setiawan, P. E. (2017). Analisis Aspek-Aspek Wajib Pajak Sebagai Anteseden Kepatuhan Wajib Pajak Kendaraan Bermotor Di Gianyar. E-Jurnal Akuntansi Universitas Udayana, 21(2), 996-1025. https://doi.org/DOI: https://doi.org/10.24843/EJA.2017.v21.i02.p05

Gersovitz, M., \& Hammer. (2013). Corrigendum to "Tax/Subsidy policies toward vector-borne infectious diseases"[J. Public Econ. 89 (2005) 647-674]. Journal of Public Economics, 104, 78. https://doi.org/10.1016/j.jpubeco.2013.06.001

Gil, P., Martí, F., Morris, R., Pérez, J. J., \& Ramos, R. (2019). The output effects of tax changes: narrative evidence from Spain. Series, 10(1), 1-23. https://doi.org/10.1007/s13209-018-0173-5

Gubernur Bali. (2011). Peraturan Daerah Provinsi Bali No.1 Tahun 2011.

Hanousek, J., \& Palda, F. (2004). Quality of government services and the civic duty to pay taxes in the Czech and Slovak Republics, and other transition countries. Kyklos, 57(2), 237-252. https://doi.org/10.1111/j.00235962.2004.00252.x

Hasnianti, \& Jamaludin. (2019). Sistem Akuntansi: Kajian Perilaku Etis Akuntan pada PT Bosowa Taksi Makassar.

Indonesia, P. R. Undang-Undang No. 28 Tahun 2009 Tentang Pajak Daerah dan Retribusi Daerah (2009).

James, S., \& Alley, C. (2009). Tax compliance, self-assessment and tax administration University of Exeter, University of Waikato. Journal of Finance and Management in Public Services, 2(2), 27-42.

Jatmiko, A. N., \& Pamudji, S. (2016). Pengaruh Sikap Wajib Pajak Pada Pelaksanaan Sanksi Denda, Pelayanan Fiskus Dan Kesadaran Perpajakan Terhadap Kepatuhan Wajib Pajak (Studi Empiris Terhadap Wajib Pajak Restoran Orang Pribadi Di Kota Manado Dan Di Kabupaten Minahasa). Accountability, 5(2), 1. https://doi.org/10.32400/ja.14420.5.2.2016.1-10

Kotler P.; Keller K. (2009). Marketing Management : International Version, 2009.

Mardiana, G. A., Wahyuni, M. A., \& Herawati, N. T. (2016). Pengaruh Self Assessment, Tingkat Pengetahuan Perpajakan, Tingkat Pendapatan, Sanksi Pajak, Persepsi Wajib Pajak Tentang Sistem Perpajakan, dan Kualitas Pelayanan Terhadap Kepatuhan Membayar Pajak (Studi Kasus Wajib Pajak 
Orang Pribadi di Kantor Pelayanan. S1 Akuntansi Universitas Pendidikan Ganesha, 6(4), 1-12.

Mardiasmo. (2018). Perpajakan Edisi Terbaru 2018. Yogyakarta: Andi.

Megawangi, C. A. M., \& Setiawan, P. E. (2017). Sosialisasi Perpajakan Memoderasi Pengaruh Kesadaran Wajib Pajak dan Kualitas Pelayanan pada Kepatuhan Wajib Pajak Badan. E-Jurnal Akuntansi Universitas Udayana, 19.3, 2348-2377.

Murti, H. W., Sondakh, J. J., \& Sabijono, H. (2014). Pelayanan Fiskus Dan Pengetahuan Perpajakan Terhadap Kepatuhan Wajib Pajak Orang Pribadi Di Kota Manado. Jurnal Riset Ekonomi, Manajemen, Bisnis Dan Akuntansi, 2(3), 389-398.

Nirajenani, C. I. P., \& Merkusiwati, N. K. L. A. (2018). Faktor-faktor yang Mempengaruhi Kepatuhan Wajib Pajak dalam Membayar Pajak Kendaraan Bermotor Fakultas Ekonomi dan Bisnis Universitas Udayana ( Unud ), Bali , Indonesia email : coknira64@yahoo.com / Telp : + 6285737795768 Fakultas Ekonomi dan Bisnis Unive, 24, 339-369.

Nisa, I. C., \& Umar, M. Pengaruh Sistem Pemungutan Pajak, Pelayanan Fiskus dan Efektifitas Sistem Perpajakan Terhadap Kepatuhan Wajib Pajak Dengan Layanan Drive Thru Sebagai Variabel Moderating, 53 Journal of Chemical Information and Modeling $\& \quad$ (2019). https://doi.org/10.1017/CBO9781107415324.004

Nurmianti, \& Thoeng, R. (2014). Pengaruh Denda, Kesadaran Wajib Pajak, Kualitas Pelayanan Fiskus, dan Kondisi Keuangan terhadap Kepatuhan Wajip Pajak Orang Pribadi di KPP Pratama Makassar Utara. UNIVERSITAS HASANUDDIN.

Oktaviani, R. M., Hardianingsih, P., \& Srimindari, C. (2017). Kepatuhan Wajib Pajak Memediasi Determinan Penerimaan Pajak Penghasilan. Jurnal Akuntansi, 21(2), 318. https://doi.org/10.24912/ja.v21i2.201

Oladipopu, A., \& Obazee, U. (2016). Tax Knowladge.

Parasuraman, A., Zeithaml, V. A., \& Berry, L. L. (1985). A Conceptual Model of Service Quality and Its Implications for Future Research. Journal of Marketing, 49(4), 41. https://doi.org/10.2307/1251430

Presiden Republik Indonesia. UU No. 25 Tentang Tentang Pelayanan Publik (2009).

Razak, A. A., \& Adafula, C. J. (2013). Evaluating taxpayers attitude and its influence on tax compliance decisions in Tamale, Ghana. Journal of Accounting and Taxation, 5(3), 48-57. https://doi.org/10.5897/jat2013.0120

Resmi, S. (2013). Perpajakan Teori dan Kasus. Journal of Chemical Information and Modeling, 53(9), 1689-1699. https://doi.org/10.1017/CBO9781107415324.004

Ronia, K. (2011). Faktor-Faktor yang Memepengaruhi Kepatuhan Wajib Pajak dalam Membayar Pajak Bumi dan Bangunan (Studi Kasus pada Kecamatan Pekalongan Utara Kabupaten Pekalongan), 1-15.

Rusmayani, N. M. L., \& Supadmi, N. L. (2018). Pengaruh Sosialisasi, Kualitas Pelayanan, Sanksi dan Biaya Kepatuhan Pada Tingkat Kepatuhan Wajib Pajak Kendaraan Bermotor. E-Jurnal Akuntansi, 20, 1. https://doi.org/10.24843/eja.2018.v25.i01.p01

Suartana, I. W. (2010). Akuntansi Keprilakuan Teori dan Implentansi.

Sugiyono. (2018). Metode Penelitian Kuantitatif dan Kualitatif. Bandung: Alfabeta. 
https://doi.org/10.1192/bjp.112.483.211-a

Sukirno, S. (2006). Makroekonomi: Teori Pengantar (3rd Editio). Jakarta: Rajawali Press.

Supriyono, R. A. (2018). Akuntansi Keprilakuan.

Suriambawa, A., \& Setiawan, P. E. (2018). Sosialisasi Perpajakan Memoderasi Pengaruh Kesadaran Wajib Pajak dan Sanksi Perpajakan Pada Kepatuhan WPOP. E-Jurnal Akuntansi, 2185. https://doi.org/10.24843/eja.2018.v25.i03.p21

Susilawati, K. E., \& Budiartha, K. (2013). Pengaruh kesadaran wajib pajak, pengetahuan pajak, sanksi perpajakan dan akuntabilitas pelayanan publik pada kepatuhan wajib pajak kendaraan bermotor. E-Jurnal Akuntansi Universitas Udayana, 2, 345-357. https://doi.org/ISSN: 2302-8556

Tri Isawati, H. Eddy Soegiarto K, T. R. (2016). Pengaruh Tingkat Pendapatan, Pengetahuan Perpajakan, Pelayanan Pajak serta Sanksi Pajak Terhadap Kepatuhan Wajib Pajak dalam Membayar Pajak Bumi Dan Bangunan (Studi Kasus di Kelurahan Teluk Lerong Ilir, Kecamatan Samarinda Ulu).

Wardani, D. K., \& Rumiyatun. (2017). Pengaruh Pengetahuan Wajib Pajak, Kesadaran Wajib Kendaraan Bermotor (Studi Kasus Wp Pkb Roda Empat di Samsat Drive Thru Bantul). Jurnal Akuntansi, 5(1). https://doi.org/10.24964/ja.v5i1.253

Webley, P., Robben, H., Ellfers, H., \& Hessing, D. (1991). Tax Evasion. 